\title{
Rejection of the Name Nocardia farcinica Trevisan 1889 (Approved Lists 1980) Request for an Opinion
}

\author{
MICHIO TSUKAMURA \\ The National Chubu Hospital, Obu, Aichi, Japan 474
}

\begin{abstract}
The name Nocardia farcinica Trevisan 1889 (Approved Lists 1980) is here considered to be a nomen dubium, and therefore it is requested that the Judical Commission issue an Opinion rejecting this name.
\end{abstract}

Before the appearance of the Approved Lists of Bacterial Names (19), the type species of the genus Nocardia was Nocardia farcinica $(12,25)$. The change of the type species to Nocardia asteroides on the Approved Lists was probably due to the proposal of Gordon and Mihm (6) to recognize $N$. asteroides as the type species. This proposal was based on the facts that these authors could not differentiate ATCC 3318, the type strain of $N$. farcinica, from strains of $N$. asteroides (thus, they considered $N$. asteroides and $N$. farcinica to be different names for the same species), that the original description of $N$. farcinica was meager, and that the name had nearly disappeared from culture collections and the current literature.

In 1969, a group of strains (the Kyoto-I group) which I received as $N$, asteroides was distinguished from other strains of $N$. asteroides (22). Based on this finding, I assigned the name $N$. farcinica to the Kyoto-I group because this group contained ATCC 3318, the type strain of $N$. farcinica, and assigned the name $N$. asteroides sensu stricto to another group. This constituted a revival of the name $N$. farcinica, which was recommended for rejection by Gordon and Mihm (6). The existence of the Kyoto-I group was confirmed subsequently by other investigators $(1,3,4,7,11,13,14,18,23,24)$. During this time, serious questions concerning the nomenclature of $N$. farcinica were raised.

First, the question of the authenticity of the type strain of $N$. farcinica was posed by Chamoiseau and Asselineau (2). These authors found mycolic acids of the mycobacterial type in strain 378 of the Pasteur Institute of Paris, which they received as an authentic strain of $N$. farcinica (that is, as one of the original strains of Nocard). Their finding meant that this supposedly authentic strain of $N$. farcinica was not a Nocardia but a Mycobacterium. Lechevalier et al. (10) studied the lipid compositions of strains labeled $N$. farcinica and found that strain NCTC 4524, which was considered to be the same as strain ATCC 3318 and was designated as a cotype strain of $N$. farcinica by Sneath and Skerman (20), contained mycolic acids characteristic of mycobacteria. According to these authors, no strain can be proved to be an authentic member of $N$. farcinica since no indisputable type strain exists for $N$. farcinica. They considered $N$. farcinica to be a nomen dubium and stated that, as proposed by Gordon and Mihm (6), the type species of the genus Nocardia should be $N$. asteroides. Doubt concerning the validity of the name $N$. farcinica was also expressed by N. M. McClung (12), H. A. Lechevalier (8), and M. P. Lechevalier (9).

Furthermore, Ridell and Norlin (17) and Ridell (16) stated that there were two kinds of strains labeled $N$. farcinica, one kind serologically related to mycobacteria and the other serologically related to nocardiae. According to the findings of these authors, ATCC 3318 belonged to Nocardia, whereas ATCC 13781, which Chamoiseau and Asselineau (2) implied was identical to the original strain of Nocard, belonged to $\mathrm{Myco}-$ bacterium. Orchard and Goodfellow (15) showed that NCTC 4524 and Mycobacterium farcinogenes strains formed one cluster in a numerical classification scheme, whereas ATCC 3318 and Nocardia strains formed another cluster.

As shown above, strains originally regarded as members of $N$. farcinica were divided into two groups, one belonging to Mycobacterium and the other belonging to Nocardia. In view of this finding, the name $N$. farcinica should be considered as a nomen dubium and should be formally rejected by the Judical Commission.

In 1980, the Approved Lists of Bacterial Names (19) were published by the International Committee on Systematic Bacteriology. However, the Approved Lists contain important inconsistencies. The name $N$. farcinica Trevisan 1889 (21) is on the Approved Lists. Nevertheless, the type species of the genus Nocardia was changed from $N$. farcinica to $N$. asteroides (Eppinger) Blanchard 1896. It is strange that the type species of Nocardia was changed from $N$. farcinica 
to $N$. asteroides and that $N$. farcinica was retained on the Approved Lists. Furthermore, a paper by Gordon and Mihm (5) is cited in the Approved Lists for the description of $N$. asteroides despite the fact that $N$. asteroides as described by Gordon and Mihm contains strain ATCC 3318 (i.e., the type strain of $N$. farcinica).

I would like to point out the following inconsistencies on the Approved Lists which are caused by the retention of the name $N$. farcinica. If, as it appears from the Approved Lists, the name $N$. farcinica, which has priority over the name $N$. asteroides, is valid, the type species of the genus Nocardia should have been N. farcinica. Therefore, a change in the type species from $N$. farcinica to $N$. asteroides should have been made after rejection of the name $N$. farcinica. Furthermore, if the name $N$. farcinica is retained, citation of the paper by Gordon and Mihm (5) is inadequate for the description of the species $N$. asteroides because, as defined by these authors, $N$. asteroides contains $N$. farcinica strains, including the type strain, ATCC 3318. A paper by Tsukamura (22) should have been cited for the description of these two species, as the species $N$. asteroides and the species Kyoto-I containing the type strain of $N$. farcinica (ATCC 3318) were initially differentiated by this author.

To eliminate the above-mentioned inconsistencies from the Approved Lists, I recommend that the name $N$. farcinica be rejected, as it is obviously a nomen dubium.

The finding of Tsukamura (22) that the KyotoI group, which contains strain ATCC 3318, is a distinct species has been supported by the findings of many other investigators $(1,3,4,8,11$, $13,14,18,23,24)$. This taxon should be named as a new species after formal rejection of the name $N$. farcinica.

\section{REPRINT REQUESTS}

Address reprint requests to: Michio Tsukamura, The National Chubu Hospital, Obu, Aichi, Japan 474.

\section{LITERATURE CITED}

1. Bradley, S. G. 1973. Relationships among mycobacteria and nocardiae based upon deoxyribonucleic acid reassociation. J. Bacteriol. 113:645-651.

2. Chamoiseau, G., and J. Asselineau. 1970. Examen des lipides de Nocardia farcinica: presence d'acides mycoliques. C.R. Acad. Sci. Ser. D 270:2603-2604.

3. Goodfellow, M. 1971. Numerical taxonomy of some nocardioform bacteria. J. Gen. Microbiol. 69:33-80.

4. Goodfellow, M., and D. E. Minnikin. 1977. Nocardioform bacteria. Annu. Rev. Microbiol. 31:159-180.

5. Gordon, R. E., and J. M. Mihm. 1957. A comparative study of some strains received as nocardiae. J. Bacteriol. 73:15-27.

6. Gordon, R. E., and J. M. Mihm. 1962. The type species of the genus Nocardia. J. Gen. Microbiol. 27:1-10.

7. Kurup, P. V., and J. A. Schmitt. 1973. Numerical taxonomy of Nocardia. Can. J. Microbiol. 19:1035-1048.

8. Lechevalier, H. A. 1977 . Report on the cooperative study of the generic assignment of strains labeled Nocardia farcinica. Actinomycetes Related Organisms 12:8-16.

9. Lechevalier, M. P. 1976. The taxonomy of the genus Nocardia: some light at the end of the tunnel?, p. 1-38. In M. Goodfellow, C. H. Brownell, and J. A. Serrano (ed.), The biology of the nocardiae. Academic Press, Inc., London.

10. Lechevalier, M. P., A. C. Horan, and H. Lechevalier. 1971. Lipid composition in the classification of nocardiae and mycobacteria. J. Bacteriol. 105:313-318.

11. Magnusson, M., and F. Mariat. 1968. Delineation of Nocardia farcinica by delayed type skin reactions on guinea pigs. J. Gen. Microbiol. 51:151-158.

12. McClung, N. M. 1974. Family IV. Nocardiaceae Castellani and Chalmers 1919, 1040, p. 726-746. In R. E. Buchanan and N. E. Gibbons (ed.), Bergey's manual of determinative bacteriology, 8th ed. The Williams \& Wilkins Co., Baltimore.

13. Mordarski, M., K. Schaal, A. Tkacz, G. Pulverer, K. Szyba, and M. Goodfellow. 1978. Deoxyribonucleic acid base composition and homology studies on Nocardia, p. 91-97. In M. Mordarski, W. Kurylowicz, and J. Jeljaszewicz (ed.), Nocardia and Streptomyces. Gustave Fischer, Stuttgart.

14. Mordarski, M., K. P. Schaal, K. Szyba, G. Pulverer, and A. Tkacz. 1977. Interrelation of Nocardia asteroides and related taxa as indicated by deoxyribonucleic acid reassociation. Int. J. Syst. Bacteriol. 27:66-70.

15. Orchard, V. A., and M. Goodfellow. 1980. Numerical classification of some named strains of Nocardia asteroides and related isolates from soil. J. Gen. Microbiol. 118:295-312.

16. Ridell, M. 1975. Taxonomic study of Nocardia farcinica using serological and physiological characters. Int. J. Syst. Bacteriol. 25:124-132.

17. Ridell, M., and M. Norlin. 1973. Serological study of Nocardia by using mycobacterial precipitation reference system. J. Bacteriol. 113:1-7.

18. Schaal, K. P., and H. Reuthersberg. 1978. Numerical taxonomy of Nocardia asteroides, p. 53-62. In M. Mordarski, W. Kurylowicz, and J. Jeljaszewicz (ed.), Nocardia and Streptomyces. Gustav Fischer, Stuttgart.

19. Skerman, V. B. D., V. McGowan, and P. H. A. Sneath (ed.). 1980. Approved lists of bacterial names. Int. J. Syst. Bacteriol. 30:225-420.

20. Sneath, P. H. A., and V. B. D. Skerman. 1966. A list of type and reference strains of bacteria. Int. J. Syst. Bacteriol. 16:1-133.

21. Trevisan, V. 1889. I generi e le specie delle Batteriacee. Zanaboni and Gabuzzi, Milan.

22. Tsukamura, M. 1969 . Numerical taxonomy of the genus Nocardia. J. Gen. Microbiol. 56:265-287.

23. Tsukamura, M. 1977. Extended numerical taxonomy study of Nocardia. Int. J. Syst. Bacteriol. 27:311-323.

24. Tsukamura, M., S. Mizuno, S. Tsukamura, and J. Tsukamura. 1979. Comprehensive numerical classification of 369 strains of Mycobacterium, Rhodococcus, and Nocardia. Int. J. Syst. Bacteriol. 29:110-129.

25. Waksman, S. A. 1957. Genus I. Nocardia Trevisan, 1889 , p. 713-741. In Bergey's manual of determinative bacteriology, 7th ed. The Williams \& Wilkins Co., Baltimore. 